\title{
Vegetative Growth and Nitrogen/Carbon Partitioning in Blueberry as Influenced by Nitrogen Fertilization
}

\author{
Donald J. Merhaut ${ }^{1}$ and Rebecca L. Darnell \\ Horticultural Sciences Department, University of Florida, Gainesville, FL 32611 \\ Additional index words. Vaccinium corymbosum, ammonium, nitrate, isotope enrichment, translocation, rhizosphere, $\mathrm{pH}$
}

\begin{abstract}
Nitrogen uptake and $\mathbf{N}$ and $\mathrm{C}$ partitioning were evaluated in 'Sharpblue' southern highbush blueberries fertilized with different $\mathbf{N}$ forms. Plants were grown in acid-washed silica sand and fertilized with a modified Hoagland's solution supplemented with $5.0 \mathrm{~mm} \mathrm{~N}$ as $\mathrm{NH}_{4}^{+}$or $\mathrm{NO}_{3}^{-}$. Nutrient solution $\mathrm{pH}$ was adjusted to 3.0 and 6.5 for the $\mathrm{NO}_{3}^{-}$and $\mathrm{NH}_{4}{ }^{+}$-treated plants, respectively. After 12 months of growth, plants were dual labeled with ${ }^{14} \mathrm{CO}_{2}$ and $10 \%$ enriched ${ }^{15} \mathrm{~N}$ $\mathrm{N}$ as either $\mathrm{NaNO}_{3}$ or $\left(\mathrm{NH}_{4}\right)_{2} \mathrm{SO}_{4}$ and harvested 12 hours after labeling. Fertilization with $\mathrm{NO}_{3}^{-}-\mathrm{N}_{\text {increased leaf, stem, and }}$ root dry weights compared to $\mathrm{NH}_{4}^{+}$fertilization. Total ${ }^{15} \mathrm{~N}$ uptake did not differ between $\mathrm{N}$ fertilization treatments, thus whole plant and $\operatorname{root}^{15} \mathrm{~N}$ concentrations were greater in $\mathrm{NH}_{4}^{+}$-fertilized vs. $\mathrm{NO}_{3}^{-}$-fertilized plants. Fertilization with $\mathrm{NO}_{3}^{-}$ -N increased $\mathrm{C}$ partitioning to new shoots compared to $\mathrm{NH}_{4}^{+}$-fertilized plants. However, $\mathrm{C}$ partitioning to other plant parts was not affected by $\mathrm{N}$ form. Although $\mathrm{NO}_{3}^{-}$uptake in blueberry appears to be restricted relative to $\mathrm{NH}_{4}^{+}$uptake, this limitation does not inhibit vegetative growth. Additionally, there appears to be adequate available carbohydrate to support concurrent vegetative growth and $\mathbf{N}$ assimilation, regardless of $\mathbf{N}$ form.
\end{abstract}

Blueberries, like most calcifuges, have adapted to acidic soils that contain $\mathrm{NH}_{4}^{+}$as the predominant $\mathrm{N}$ form (Korcak, 1988). Several studies indicate that leaf $\mathrm{N}$ concentration and vegetative growth increase in highbush (Vaccinium corymbosum L.) and lowbush (V. angustifolium Ait.) blueberry and cranberry (V. macrocarpon Ait.) when fertilized with $\mathrm{NH}_{4}^{+}-\mathrm{N}$ vs. $\mathrm{NO}_{3}^{-}-\mathrm{N}$ (Cain, 1952; Greidanus et al., 1972; Peterson et al., 1988; Townsend, $1967 ; 1970)$. In other studies, no differences in vegetative growth due to $\mathrm{N}$ form have been observed (Hammett and Ballinger, 1972; Oertli, 1963; Takamizo and Sugiyama, 1991).

Differences in growth may be due to differences in rhizosphere $\mathrm{pH}$ in addition to $\mathrm{N}$ form. In a factorial experiment of three $\mathrm{N}$ forms $\left(\mathrm{NH}_{4}^{+}, \mathrm{NH}_{4} \mathrm{NO}_{3}\right.$, and $\left.\mathrm{NO}_{3}{ }^{-}\right)$and two $\mathrm{pH}$ levels (4.5 and 6.5), Rosen et al. (1990) found that 'Northblue' halfhigh blueberry (V. corymbosum L. $\times$ V. angustifolium Ait.) produced significantly more vegetative growth when grown hydroponically at $\mathrm{pH} 4.5$ vs. 6.5, regardless of $\mathrm{N}$ form. At a given $\mathrm{pH}$, vegetative growth was not affected by $\mathrm{N}$ form. In a similar study with hydroponically grown cranberry, vegetative growth was significantly greater in plants supplemented with $\mathrm{NH}_{4}^{+}-\mathrm{N}$ compared to $\mathrm{NO}_{3}^{-}-\mathrm{N}$, and in plants grown at $\mathrm{pH} 4.5$ vs. $\mathrm{pH} 6.0$. There was no $\mathrm{pH} \times \mathrm{N}$ form interaction. However, Sugiyama and Hanawa (1992) observed an interaction between $\mathrm{N}$ form and $\mathrm{pH}$ in the growth response of hydroponically grown 'Tifblue' rabbiteye blueberry ( $V$. ashei Reade). Shoot dry weight was greater in $\mathrm{NH}_{4}^{+}$-fertilized plants vs. $\mathrm{NO}_{3}^{-}$-fertilized plants at $\mathrm{pH} 3.0$ and 4.0; however, there was no difference in shoot growth between $\mathrm{N}$ forms at $\mathrm{pH}$ 5.0. Although results from these experiments are not consistent, it is clear that $\mathrm{pH}$ can be a major factor in determining effects of $\mathrm{N}$ form on growth.

Growth differences attributed to different $\mathrm{N}$ forms and/or rhizosphere $\mathrm{pH}$ regimes may be due to differences in $\mathrm{N}$ uptake/

Received for publication 14 Sept. 1995. Accepted for publication 12 Feb. 1996 University of Florida journal series no. R-04974. The cost of publishing this paper was defrayed in part by the payment of page charges. Under postal regulations, this paper therefore must be hereby marked advertisement solely to indicate this fact. ${ }^{1}$ Former graduate research assistant. Currently, postdoctoral fellow, U.S. Dept. of Agricultural, Agricultural Research Service, Children's Nutrition Research Center, Dept. of Pediatrics, Baylor College of Medicine, 1100 Bates Street, Houston, TX 77030 . assimilation patterns within the plant and/or differences in carbohydrate partitioning. Several studies indicate that $\mathrm{NO}_{3}{ }^{-} \mathrm{N}$ uptake by blueberry is limited compared to $\mathrm{NH}_{4}{ }^{+}-\mathrm{N}$ uptake (Merhaut and Darnell, 1995; Peterson et al., 1988; Sugiyama and Hirooka, 1993; Sugiyama and Ishigaki, 1994), and this limitation has been associated with growth reduction in blueberries fertilized with $\mathrm{NO}_{3}{ }_{-}^{-} \mathrm{N}$. It has not been clearly demonstrated, however, that the reduced growth sometimes observed in $\mathrm{NO}_{3}^{-}$-fertilized blueberries is due to limitations in $\mathrm{NO}_{3}^{-}$uptake.

The availability of carbohydrates to the site of $\mathrm{N}$ assimilation may have a marked effect on the extent of $\mathrm{N}$ uptake and/or assimilation and growth, since assimilation of both $\mathrm{N}$ forms requires $\mathrm{C}$ skeletons. In many herbaceous species, $\mathrm{NO}_{3}{ }^{-}-\mathrm{N}$ uptake and reduction appear to be carbohydrate limited after a period of darkness or during leaf development, when a significant decline in carbohydrate availability to the roots may occur. This limitation is closely correlated with rates of current carbohydrate flux from shoots to roots, rather than the carbohydrate status of the roots directly (Rideout and Raper, 1994). Similarly, $\mathrm{NH}_{4}^{+}-\mathrm{N}$ uptake and assimilation appears to be limited if there is insufficient current carbohydrate available to roots (Tolley-Henry and Raper, 1989). Reduction in growth of $\mathrm{NH}_{4}^{+}$-fertilized plants has been attributed to the allocation of current $\mathrm{C}$ to support $\mathrm{NH}_{4}^{+}-\mathrm{N}$ assimilation rather than root growth (Lewis et al., 1987).

There are limited studies on effects of carbohydrate availability on $\mathrm{N}$ uptake in perennial species. Weinbaum et al. (1978) reported that nonbearing prune trees (Prunus domestica L.) exhibited high $\mathrm{NO}_{3}{ }^{-} \mathrm{N}$ uptake rates during rapid shoot development, suggesting that carbohydrate availability for $\mathrm{NO}_{3}{ }^{-} \mathrm{N}$ uptake may not be limiting in woody perennials. However, $\mathrm{NO}_{3}^{-}-\mathrm{N}$ uptake in holly (Ilex crenata Thumb.) was greatest between vegetative growth flushes (Gilliam and Wright, 1978), suggesting that insufficient C was available to support both $\mathrm{N}$ uptake and vegetative growth. Uptake rates of $\mathrm{NH}_{4}{ }^{+}-\mathrm{N}$ and $\mathrm{NO}_{3}{ }^{-}-\mathrm{N}$ as influenced by the availability of current $\mathrm{C}$ to roots, and the correlation with subsequent growth responses, have not been studied in blueberry.

The objective of the present study was to determine the effects of fertilization with $\mathrm{NH}_{4}^{+}-\mathrm{N}$ or $\mathrm{NO}_{3}^{-}-\mathrm{N}$ on vegetative growth of southern highbush (V. corymbosum L. interspecific hybrid) blue- 
berries. Uptake and partitioning patterns of $\mathrm{NO}_{3}{ }^{-}$and $\mathrm{NH}_{4}^{+}$, as well as partitioning patterns of current $\mathrm{C}$, were determined also in an attempt to relate differences in these processes to the observed growth responses.

\section{Materials and Methods}

Plant material. Rooted cuttings of 'Sharpblue' southern highbush blueberry were grown for two years in 12-L pots containing $50 \%$ 'Arrendondo fine sand' and 50\% perlite. During the 2-year pretreatment period, plants were fertilized every other week with $250 \mathrm{mg} 20 \mathrm{~N}-8.7 \mathrm{P}-16.6 \mathrm{~K}$ containing $20 \% \mathrm{~N}$ as $\left(\mathrm{NH}_{4}\right)_{2} \mathrm{HPO}_{4}, 30 \%$ $\mathrm{N}$ as $\mathrm{KNO}_{3}$, and $50 \% \mathrm{~N}$ as urea. In March 1992, plants, which had about $200 \mathrm{~cm}$ of shoot growth, were removed from the containers and roots were cleaned of soil before repotting in 12-L pots containing acid-washed 20/30-mesh silica sand. Plants were grown from March 1992 to March 1993 in a greenhouse where day/night temperatures were maintained at $30 \pm 7 / 18 \pm 4{ }^{\circ} \mathrm{C}$. On 20 Sept., daylength was extended to $14 \mathrm{~h}$ by installing fluorescent and incandescent lamps, which produced a PPF of $120 \mu \mathrm{mol} \cdot \mathrm{m}^{-2} \cdot \mathrm{s}^{-1}$ at the top of the plant canopy.

Nutrient solution treatments. Plants were fertilized every other day with $1 \mathrm{~L}$ of a modified Hoagland's solution consisting of (mmol): $5.0 \mathrm{~N}, 1.4 \mathrm{P}, 1.0 \mathrm{~K}, 0.5 \mathrm{Ca}, 1.0 \mathrm{Mg}, 0.4 \mathrm{Na}, 1.7 \mathrm{~S}, 1.0 \mathrm{Cl}$, $9.0 \times 10^{-2} \mathrm{Fe}, 4.5 \times 10^{-2} \mathrm{~B}, 9.1 \times 10^{-2} \mathrm{Mn}, 1.1 \times 10^{-2} \mathrm{Zn}, 1.6 \times 10^{-3} \mathrm{Cu}$, and $2.1 \times 10^{-3}$ Mo. The iron source was Fe-EDTA chelate.

Treatments consisted of fertilization with either $\mathrm{NH}_{4}^{+}$derived from $\left(\mathrm{NH}_{4}\right)_{2} \mathrm{SO}_{4}$ or $\mathrm{NO}_{3}{ }^{-}$derived from $\mathrm{NaNO}_{3}$. Therefore, there was an additional $2.6 \mathrm{mmol} \mathrm{S}$ supplied to the $\mathrm{NH}_{4}^{+}$treatments and an additional $5.0 \mathrm{mmol} \mathrm{Na}$ supplied to the $\mathrm{NO}_{3}{ }^{-}$treatments at each fertilization time. The initial nutrient solution $\mathrm{pH}$ was adjusted to

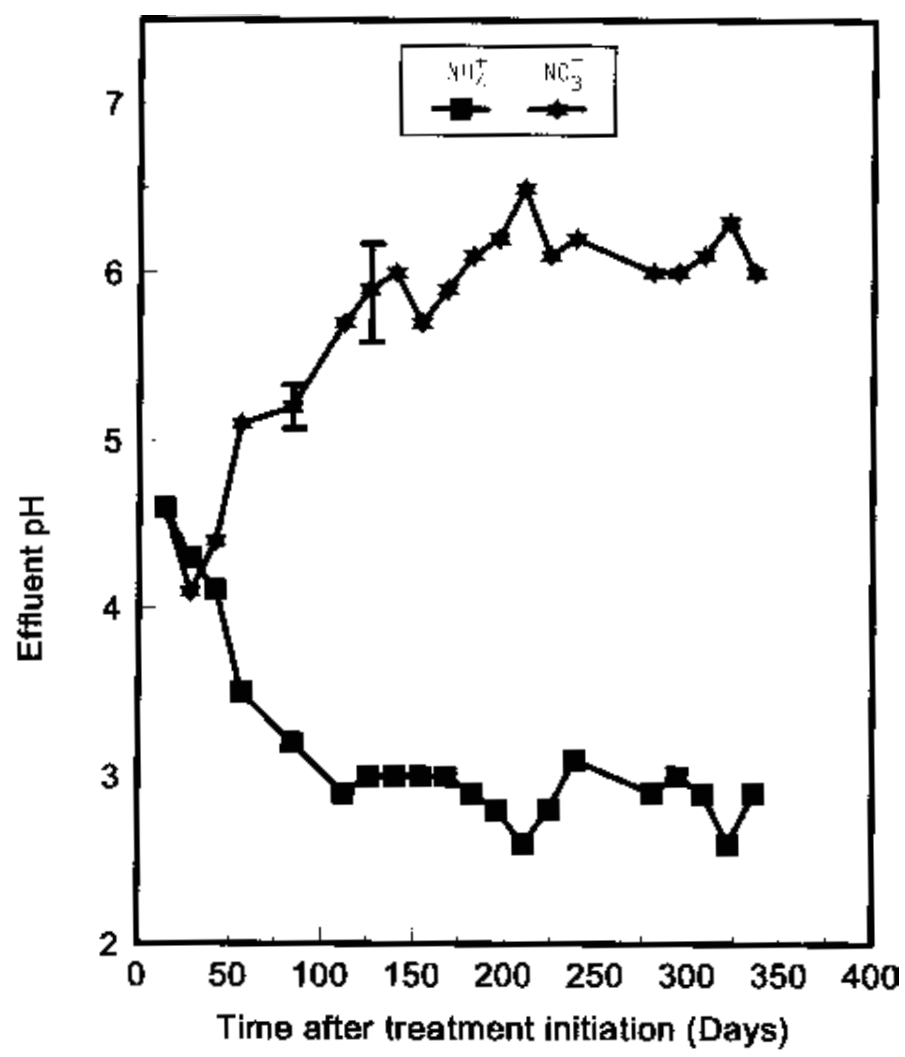

Fig. 1. Change in effluent pH during the 336 days of growth for 'Sharpblue' blueberry plants fertilized with either $\mathrm{NH}_{4}^{+}$or $\mathrm{NO}_{3}^{-}$. (means $\pm \mathrm{SE}, \mathrm{n}=5$, $\mathrm{SE}$ bars present only when larger than symbol).
3.0 for the $\mathrm{NO}_{3}^{-}-\mathrm{N}$ solution and 6.5 for the $\mathrm{NH}_{4}^{+}-\mathrm{N}$ solution using $\mathrm{HCl}$ or $\mathrm{Ca}(\mathrm{OH})_{2}$. Effluent $\mathrm{pH}$ was monitored after fertilization treatments, every other week by collecting the leachate in trays placed under the pots. Effluents were also analyzed for $\mathrm{NH}_{4}^{+}$and $\mathrm{NO}_{3}{ }^{-}$content to verify that nitrification or reduction did not occur. Less than $0.02 \mathrm{~mm} \mathrm{NO}_{3}^{-}$was recovered in the leachate from the $\left(\mathrm{NH}_{4}\right)_{2} \mathrm{SO}_{4}$ treatment. Additionally, there was no evidence of $\mathrm{NH}_{4}^{+}$ contamination in leachates from the $\mathrm{NaNO}_{3}$ treatment.

The $\mathrm{pH}$ regimes used in the present study were selected based on two preliminary studies (Merhaut, 1993). In the first of these studies, nutrient solution $\mathrm{pH}$ was maintained at 5.5 for both solutions. Effluent $\mathrm{pH}$ of the $\mathrm{NO}_{3}^{-}$-treated plants increased continuously with each fertilization, which was accompanied by interveinal leaf chlorosis, suggesting Fe deficiency. Effluent $\mathrm{pH}$ of the $\mathrm{NH}_{4}^{+}$-treated plants decreased continuously with each fertilization, reaching values less than 3.0. In the second preliminary experiment, initial nutrient solution $\mathrm{pH}$ for both treatments was adjusted to 5.5 as before; however, the nutrient solution $\mathrm{pH}$ was increased or decreased as the effluent $\mathrm{pH}$ decreased or increased in the $\mathrm{NH}_{4}^{+}-\mathrm{N}$ and $\mathrm{NO}_{3}^{-}-\mathrm{N}$ fertilized plants, respectively. Therefore, NO3- nutrient solution $\mathrm{pH}$ was decreased to 4.0 after 98 days of growth, in an attempt to prevent Fe deficiency symptoms. At the same time, the $\mathrm{NH}_{4}^{+}$nutrient solution $\mathrm{pH}$ was increased to 6.5 to prevent rhizosphere $\mathrm{pH}$ below 3.0, which can result in $\mathrm{Ca}, \mathrm{Mg}$, and K deficiency (Brady, 1990). However, slight chlorosis of young shoots still occurred in $\mathrm{NO}_{3}{ }^{-}$-fertilized plants. Therefore, in the present study, nutrient solution $\mathrm{pH}$ was adjusted to 3.0 and 6.5 for the $\mathrm{NO}_{3}^{-}-\mathrm{N}$ and $\mathrm{NH}_{4}{ }^{+} \mathrm{N}$ treatments, respectively at the beginning of the experiment. No visual nutrient deficiency symptoms were observed in either treatment throughout the one year experimental period.

To characterize further the effects of the $\mathrm{NH}_{4}^{+}$and $\mathrm{NO}_{3}^{-}-$ nutrient solutions on plant development, leaf tissue analyses were conducted. Mature leaves of the second vegetative flush were collected, oven dried at $70^{\circ} \mathrm{C}$, and ground to 40 mesh $(0.417 \mathrm{~mm})$ with a Wiley mill (Arthur H. Thomas Co., Philadelphia). A 500-mg tissue sample was placed in a ceramic mortar and ashed at $500{ }^{\circ} \mathrm{C}$ for $4 \mathrm{~h}$. Ashed samples were suspended in $50 \mathrm{~mL} 1 \mathrm{~N} \mathrm{HCl}$, and filtered through no. 2 Whatman filter paper. Elemental concentrations of $\mathrm{P}, \mathrm{K}, \mathrm{Ca}, \mathrm{Mg}, \mathrm{Fe}, \mathrm{Mn}, \mathrm{Cu}, \mathrm{B}$, and $\mathrm{Zn}$ in solutions were quantified on an inductively coupled argon plasma spectrophotometer (ICAP-9000) (Thermo Jarrell-Ash Corp., Franklin, Mass.). Sulfur concentrations were determined by a Leco S analyzer (Leco Corp., St. Joseph, Mich.).

Nitrogen and $C$ partitioning. At the end of the treatment period, when the plants were midway through the fourth growth flush, they were dual labeled with $105 \mathrm{mg} \mathrm{N}$ as $10 \%{ }^{15} \mathrm{~N}$-enriched $\left(\mathrm{NH}_{4}\right)_{2} \mathrm{SO}_{4}$ or $\mathrm{NaNO}_{3}$ (Isotec Inc., Miamisburg, Ohio) and ${ }^{14} \mathrm{CO}_{2}$. Nitrogen was dissolved in $0.5 \mathrm{~L}$ deionized water and applied as a soil drench at 10:00 AM, $3 \mathrm{~h}$ after sunrise. No ${ }^{15} \mathrm{~N}$-labeled solution leached out of the pots at the time of labeling. Immediately following ${ }^{15} \mathrm{~N}$ labeling, plants were labeled with ${ }^{14} \mathrm{CO}_{2}$. Shoots of each plant were enclosed in a $48 \times 60$-cm clear bag and ${ }^{14} \mathrm{CO}_{2}$ was generated by reacting $1.30 \mathrm{MBq}^{14} \mathrm{C}-\mathrm{NaHCO}_{3}$ (s.a. $2.2 \mathrm{GBq} \cdot \mathrm{mmol}^{-1}$ ) with $70 \mu \mathrm{L}$ $10 \% \mathrm{H}_{2} \mathrm{SO}_{4}$ inside an eppendorf tube within the bag. After $1 \mathrm{~h}$, bags were removed. PPF and temperature averaged $950 \mu \mathrm{mol} \cdot \mathrm{m}^{-2} \cdot \mathrm{s}^{-1}$ and $21{ }^{\circ} \mathrm{C}$, respectively, during the $1 \mathrm{~h}^{14} \mathrm{C}$-labeling period. During the 12-h period following ${ }^{15} \mathrm{~N}$ and ${ }^{14} \mathrm{C}$ labeling, air temperatures increased from $21{ }^{\circ} \mathrm{C}$ at 10:00 AM to $30{ }^{\circ} \mathrm{C}$ at 3:30 PM, before decreasing to $21^{\circ} \mathrm{C}$ by 9:30 PM. PPF averaged 800, 1440, and 124 $\mu \mathrm{mol} \cdot \mathrm{m}^{-2} \cdot \mathrm{s}^{-1}$ at 9:30 $\mathrm{AM}, 1: 00 \mathrm{PM}$, and 6:00 $\mathrm{PM}$, respectively. After $12 \mathrm{~h}$, plants were harvested, and total stem length and leaf area were measured. Plants were divided into roots, stems, leaves, and 
Table 1. Leaf nutrient concentrations of 'Sharpblue' blueberry plants fertilized with $\mathrm{NH}_{4}^{+}$or $\mathrm{NO}_{3}{ }^{-}$.

\begin{tabular}{|c|c|c|c|c|c|c|c|c|c|c|c|}
\hline & \multicolumn{11}{|c|}{ Leaf nutrient concn } \\
\hline & \multicolumn{6}{|c|}{$\mathrm{mg} \cdot \mathrm{g}^{-1}$ dry wt } & \multicolumn{5}{|c|}{$\mu \mathrm{g} \cdot \mathrm{g}^{-1}$ dry wt } \\
\hline & $\mathrm{Ca}$ & $\mathrm{Mg}$ & $\mathrm{K}$ & $S$ & $\mathrm{Na}$ & $\mathrm{P}$ & $\mathrm{Zn}$ & $\mathrm{Cu}$ & $\mathrm{Mn}$ & $\mathrm{Fe}$ & B \\
\hline $\mathrm{NH}_{4}^{+}$ & 4.1 & 2.9 & 12.3 & 6.4 & 0.2 & 2.1 & 31 & 3 & 57 & 37 & 108 \\
\hline \multirow{2}{*}{$\mathrm{NO}_{3}^{-}$} & 4.3 & 2.0 & 9.1 & 2.5 & 10.7 & 1.5 & 27 & 5 & 44 & 36 & 126 \\
\hline & NS & $*$ & $*$ & $*$ & $*$ & $*$ & NS & $*$ & NS & NS & $*$ \\
\hline
\end{tabular}

$\overline{\text { ss, }}{ }^{*}$ Nonsignificant or significant at $P=0.05$ by $t$ test.

new shoots (new stem and leaf tissue of the fourth flush), frozen in liquid $\mathrm{N}_{2}$, oven dried at $70^{\circ} \mathrm{C}$, and ground to 40 mesh $(0.417 \mathrm{~mm})$ with a Wiley mill. Tissue $\mathrm{N}$ was determined by combusting and oxidizing $3 \mathrm{mg}$ subsamples and quantifying the evolved $\mathrm{N}_{2}$ on a NA 1500 gas chromatograph (Carlo Erba, Strada Riboltana, Italy). The percentage of ${ }^{15} \mathrm{~N}$ was determined by mass spectrophotometry (Vaccume Generators 602E, England).

To determine total ${ }^{14} \mathrm{C}$ activity, $50 \mathrm{mg}$ of dried tissue was extracted in boiling $80 \%$ ethanol for 2 min. Extracts were shaken for $20 \mathrm{~min}$, centrifuged at $3500 \times g$ for $10 \mathrm{~min}$, the supernatant decanted, and the pellet reextracted twice. The supernatants were combined and final volumes were measured. The ${ }^{14} \mathrm{C}$ activity of a 1-mL aliquot was determined by liquid scintillation spectroscopy (LKB Instruments, Inc., Gaithersburg, Md.). The pellet was resuspended in $1 \mathrm{~mL} \mathrm{H}_{2} \mathrm{O}$, solubilized with $250 \mu \mathrm{L}$ tissue solubilizer (TS-1; Research Products International Corp., Mount Prospect, Ill.), and incubated at $60^{\circ} \mathrm{C}$ for $12 \mathrm{~h}$. Following incubation, $25 \mu \mathrm{L}$ $0.1 \%$ acetic acid was added and samples were refrigerated $12 \mathrm{~h}$ to decrease chemiluminescence. The ${ }^{14} \mathrm{C}$ activity of a $0.5-\mathrm{mL}$ aliquot was determined. Total ${ }^{14} \mathrm{C}$ activity of a tissue was calculated by adding the ${ }^{14} \mathrm{C}$ activity of the ethanol-soluble and pellet fractions.

Statistical analysis. The experimental design was a randomized complete-block design with ten plants providing five replications of two treatments. The block effect was included due to the temperature gradient in the greenhouse. However, because there were no block $\times$ treatment interactions, these data were not presented. All treatment effects were analyzed by ANOVA using SAS (Cary, N.C.) with mean separation by Student $t$ test.

\section{Results and Discussion}

Treatment $\mathrm{pH}$. Effluent $\mathrm{pH}$ decreased in the $\mathrm{NH}_{4}^{+}$-fertilized plants during the first 140 days of growth, stabilizing at about 3.0, while effluent $\mathrm{pH}$ in the $\mathrm{NO}_{3}^{-}$-fertilized plants increased, stabilizing at about 6.0 (Fig. 1). This gradual change in effluent $\mathrm{pH}$ is similar to changes observed in other studies (Hewitt, 1966; Townsend, 1967), and apparently reflects exchange of $\mathrm{H}^{+}$and $\mathrm{OH}^{-}$ for $\mathrm{NH}_{4}^{+}$and $\mathrm{NO}_{3}^{-}$, respectively, and/or cotransport of $\mathrm{H}^{+}$with $\mathrm{NO}_{3}^{-}$(McClure et al., 1990a, 1990b).

Nutrient analysis. Elemental analysis of leaf tissue and visual observations of leaves and roots indicated that concentrations of most nutrients were within the normal range for blueberry growth (Table 1) (Austin and Gaines, 1984; Ballinger, 1962; Clark, 1988;
Eck, 1988; Korcak, 1986; Peterson et al., 1988; Spiers, 1978; $1983 \mathrm{a}$; 1983b), with the exception of B, which was high, and Fe, which was low in leaf tissue of both treatments. Additionally, $\mathrm{Na}$ concentrations in the $\mathrm{NO}_{3}^{-}$-fertilized plants were high. Although Fe concentrations were below the sufficiency range, there was no difference in $\mathrm{Fe}$ concentration between $\mathrm{N}$ forms. Additionally, no visual symptoms of Fe deficiency, such as interveinal leaf chlorosis (Eck, 1988), occurred. This suggests that Fe was physiologically available for plant growth and development, and was not a contributing factor to the growth differences observed with different $\mathrm{N}$ treatments. Leaf necrosis associated with excess $\mathrm{Na}$ was not observed in the $\mathrm{NO}_{3}^{-}$treatments in the present study, even though others have reported leaf necrosis on blueberry plants when $\mathrm{Na}$ concentrations in mature leaves were above $5.0 \mathrm{mg} \cdot \mathrm{g}^{-1}$ dry weight (Haby et al., 1986). Overall visual observations of shoot and root tissue indicated no apparent nutrient deficiency or toxicity symptoms in either treatment. Together, these data indicate that proper nutrient balances for both $\mathrm{N}$ treatments were maintained.

Leaf concentrations of $\mathrm{Mg}, \mathrm{K}, \mathrm{S}$, and $\mathrm{P}$ were significantly greater in the $\mathrm{NH}_{4}{ }^{+}-\mathrm{N}$ compared to the $\mathrm{NO}_{3}^{-}-\mathrm{N}$ fertilized plants, while $\mathrm{Cu}$ and $\mathrm{B}$ were lower (Table 1). Similar effects on $\mathrm{Mg}, \mathrm{K}$, and $\mathrm{S}$ concentration have been found in studies in which the $\mathrm{NH}_{4}^{+}$and $\mathrm{NO}_{3}^{-}$sources were $\left(\mathrm{NH}_{4}\right)_{2} \mathrm{SO}_{4}$ and $\mathrm{NaNO}_{3}$ (Spiers, 1978; Townsend, 1967). In other studies, where $\mathrm{Ca}\left(\mathrm{NO}_{3}\right)_{2}$ was used as the $\mathrm{NO} 3$ source, concentrations of $\mathrm{Mg}$ and $\mathrm{K}$ were higher in $\mathrm{NO}_{3}^{-}-\mathrm{N}$ compared to $\mathrm{NH}_{4}^{+}-\mathrm{N}$ fertilized plants (Peterson et al., 1988; Rosen et al., 1990). These effects of $\mathrm{NH}_{4}^{+}$and $\mathrm{NO}_{3}{ }^{-}$on $\mathrm{Mg}$ and $\mathrm{K}$ concentration may be due to the competition of the counter ions (i.e., Na or Ca) with other elements for uptake (Glass, 1989).

Vegetative growth. Leaf, stem, root, and total plant dry weights, as well as total stem length, were significantly greater in the $\mathrm{NO}_{3}^{-}$ $-\mathrm{N}$ compared to the $\mathrm{NH}_{4}^{+}-\mathrm{N}$ fertilized plants (Table 2). The increased growth of blueberry when fertilized with $\mathrm{NO}_{3}^{-}-\mathrm{N}$ vs. $\mathrm{NH}_{4}{ }^{+}-\mathrm{N}$ differs from other studies (Hammett and Ballinger, 1972; Oertli, 1963; Rosen et al., 1990), where $\mathrm{NO}_{3}{ }^{-} \mathrm{N}$ produced equal or less vegetative growth than $\mathrm{NH}_{4}^{+}-\mathrm{N}$ fertilized plants. It appears that blueberry can effectively utilize $\mathrm{NO}_{3}^{-}-\mathrm{N}$, as long as rhizosphere $\mathrm{pH}$ is within an appropriate range. Acidic conditions in the rhizosphere may increase $\mathrm{NO}_{3}^{-}$- uptake due to increased $\mathrm{H}+/ \mathrm{NO}_{3}^{-}$ symport (McClure et al., 1990a, 1990b). Such enhancement of $\mathrm{NO}_{3}^{-}$uptake at low rhizosphere $\mathrm{pH}$ would be consistent with the observation that blueberry growth is often independent of $\mathrm{N}$ form at acidic pH (Rosen et al., 1990).

Table 2. Vegetative growth of 'Sharpblue' blueberry plants fertilized with $\mathrm{NH}_{4}{ }^{+}$or $\mathrm{NO}_{3}{ }^{-}$.

\begin{tabular}{|c|c|c|c|c|c|c|c|}
\hline & \multicolumn{5}{|c|}{ Dry wt (g) } & \multirow{2}{*}{$\begin{array}{l}\text { Total leaf } \\
\text { area }\left(\mathrm{cm}^{2}\right)\end{array}$} & \multirow{2}{*}{$\begin{array}{l}\text { Total stem } \\
\text { length }(\mathrm{cm})\end{array}$} \\
\hline & Plant & New shoot & Leaf & Stem & Root & & \\
\hline $\mathrm{NH}_{4}^{+}$ & 417.2 & 49.6 & 58.8 & 121.6 & 187.2 & 13988 & 1604.4 \\
\hline \multirow{2}{*}{$\mathrm{NO}_{3}^{-}$} & 701.2 & 48.6 & 107.4 & 247.2 & 298.0 & 17892 & 2056.4 \\
\hline & $*$ & NS & $*$ & $*$ & $*$ & NS & $*$ \\
\hline
\end{tabular}

$\mathrm{Ns}^{*}$ Nonsignificant or significant at $P=0.05$ by $t$ test. 
Table 3. Nitrogen concentration in the vegetative tissue of 'Sharpblue' blueberry plants fertilized with $\mathrm{NH}_{4}^{+}$or $\mathrm{NO}_{3}{ }^{-}$.

\begin{tabular}{lcccc}
\hline & \multicolumn{4}{c}{ Nitrogen concn $\left(\mathrm{mg} \cdot \mathrm{g}^{-1}\right.$ dry wt $)$} \\
\cline { 2 - 5 } & New shoots & Leaves & Stems & Roots \\
\hline $\mathrm{NH}_{4}^{+}$ & 18.0 & 14.6 & 7.7 & 8.2 \\
$\mathrm{NO}_{3}^{-}$ & 16.8 & 12.4 & 4.3 & 7.2 \\
& NS & $*$ & $*$ & NS \\
\hline
\end{tabular}

Ns, ${ }^{*}$ Nonsignificant or significant at $P=0.05$ by $t$ test.

Nitrogen concentrations, uptake, and partitioning. Leaf $\mathrm{N}$ concentration was significantly greater in the $\mathrm{NH}_{4}^{+}$vs. $\mathrm{NO}_{3}^{-}$fertilized plants, averaging 15 and $12 \mathrm{mg} \mathrm{N} / \mathrm{g}$ dry weight, respectively (Table 3 ). The $\mathrm{N}$ concentration in the $\mathrm{NO}_{3}^{-}$-fertilized leaf tissue is slightly lower than the average for other southern highbush blueberry cultivars (Clark, 1988). Nitrogen concentrations in stems was also greater in $\mathrm{NH}_{4}^{+}{ }^{+} \mathrm{N}$ treatments, while $\mathrm{N}$ concentrations in new shoots and roots were similar between the two treatments. Higher $\mathrm{N}$ concentrations have been observed in roots (Hammett and Ballinger, 1972; Peterson et al., 1988), shoots (Takamizo and Sugiyama, 1991), or both roots and shoots (Rosen et al., 1990; Townsend, 1969) of $\mathrm{NH}_{4}^{+}$- compared to $\mathrm{NO}_{3}^{-}$-fertilized plants. In general, the increased leaf $\mathrm{N}$ concentration does not typically correlate with increased vegetative growth (Rosen et al., 1990; Smith et al., 1990; Spiers, 1983a; Sugiyama and Hanawa, 1992). In rabbiteye blueberry, greater shoot growth occurred in $\mathrm{NH}_{4}^{+}$vs. $\mathrm{NO}_{3}{ }^{-}$treatments when grown at $\mathrm{pH} 3.0$ or 4.0 , but equal shoot growth between $\mathrm{N}$ treatments occurred when grown in solution pH 6.0 (Sugiyama and Hanawa, 1992). These growth responses could not be readily explained by tissue $\mathrm{N}$ concentrations, which were consistently higher in $\mathrm{NH}_{4}^{+}$vs. $\mathrm{NO}_{3}^{-}$treatments, regardless of solution $\mathrm{pH}$. Similarly, Rosen et al. (1990) found greater $\mathrm{N}$ concentrations in tissues of $\mathrm{NH}_{4}^{+}$vs. $\mathrm{NO}_{3}^{-}$-treated plants, even though no differences in plant growth were observed between the two $\mathrm{N}$ forms. These studies and the present experiment indicate that increased leaf $\mathrm{N}$ concentrations do not necessarily correlate with increased vegetative growth.

Total $\mathrm{N}$ accumulation derived from ${ }^{15} \mathrm{~N}$-fertilizer did not differ between $\mathrm{N}$ treatments during the 12-h uptake period, averaging 45 and $43 \mathrm{mg} \mathrm{N}$ for $\mathrm{NH}_{4}^{+}$- and $\mathrm{NO}_{3}^{-}$-fertilized plants, respectively (Table 4). This occurred despite the greater plant dry weight of the $\mathrm{NO}_{3}$-fertilized plants. Uptake rates over the 12 -h period averaged about $10 \mu \mathrm{g} \mathrm{N} / \mathrm{g}$ plant dry weight per $\mathrm{h}$ for $\mathrm{NH}_{4}^{+}$-fertilized plants, and about $6 \mu \mathrm{g} \mathrm{N} / \mathrm{g}$ plant dry weight per h for $\mathrm{NO}_{3}^{-}$-fertilized plants. Although these rates are somewhat less than the uptake rates observed in blueberries fertilized previously with $\mathrm{NH}_{4} \mathrm{NO}_{3}$, these findings support the earlier observation that $\mathrm{NH}_{4}^{+}-\mathrm{N}$ uptake rates in blueberry were 2 -fold greater than $\mathrm{NO}_{3}^{-}-\mathrm{N}$ uptake rates
(Merhaut and Darnell, 1995). The partitioning of ${ }^{15} \mathrm{~N}$-fertilizerderived $\mathrm{N}$ to the new shoots, leaves, stems, and roots was not affected by $\mathrm{N}$ treatment. Of the total ${ }^{15} \mathrm{~N}$-fertilizer $\mathrm{N}$ taken up, $17 \%$ and $26 \%$ was recovered in the shoots of the $\mathrm{NH}_{4}^{+}$- and $\mathrm{NO}_{3}^{-}$fertilized plants, respectively (Table 4).

The increased uptake rates in $\mathrm{NH}_{4}^{+}$-fertilized plants led to increased concentration of ${ }^{15} \mathrm{~N}$-fertilizer-derived $\mathrm{N}$ in the whole plant compared to the $\mathrm{NO}_{3}^{-}$treatments (Table 4). This was due primarily to a significantly higher $\mathrm{N}$ concentration in roots of $\mathrm{NH}_{4}{ }^{+}$- vs. $\mathrm{NO}_{3}^{-}$-fertilized plants. The concentration of ${ }^{15} \mathrm{~N}$-fertilizer-derived $\mathrm{N}$ in new shoots, leaves and stems was not affected by $\mathrm{N}$ form. The decreased $\mathrm{N}$ concentration in roots of $\mathrm{NO}_{3}^{-}$-fertilized plants may reflect decreased $\mathrm{NO}_{3}^{-}$reduction due to low nitrate reductase activity (NRA) (Merhaut, 1993) and the subsequent feedback inhibition of $\mathrm{NO}_{3}^{-}$uptake.

Although these data indicate that $\mathrm{NO}_{3}{ }^{-} \mathrm{N}$ uptake is restricted in blueberry compared to $\mathrm{NH}_{4}^{+}-\mathrm{N}$ uptake, this restriction clearly does not lead to inhibition of growth in $\mathrm{NO}_{3}^{-}$-fertilized plants. In fact, growth increased in $\mathrm{NO}_{3}^{-}$-fertilized plants compared to $\mathrm{NH}_{4}^{+}-$ fertilized plants despite this restriction in $\mathrm{NO}_{3}^{-}$uptake.

Carbon partitioning. The partitioning of ${ }^{14} \mathrm{C}$-labeled photosynthates is expressed as the relative specific activity (RSA) (Brun and Betts, 1984):

\section{$\mathrm{RSA}=($ dpm of plant organ/total dpm of plant $) /($ dry weight of plant organ/total plant dry weight)}

The RSA normalizes for differences in ${ }^{14} \mathrm{C}$ uptake and recovery and allows estimation of the extent of $\mathrm{C}$ partitioning to a particular plant organ relative to its mass. Significantly more current $\mathrm{C}$ was partitioned to new shoots of $\mathrm{NO}_{3}^{-}$-fertilized plants compared to $\mathrm{NH}_{4}{ }^{+}$-fertilized plants (Table 5). Carbon partitioning to other organs was not affected by $\mathrm{N}$ treatment. The increased allocation of $\mathrm{C}$ to new shoots of $\mathrm{NO}_{3}{ }^{-}$-fertilized vs. $\mathrm{NH}_{4}^{+}$-fertilized plants may be a reflection of $\mathrm{NO}_{3}^{-}$reduction occurring in the leaves, as is the case in many herbaceous crops (Lewis et al., 1987). Wang and Korcak (1995) have detected NRA in mature leaves of northern highbush and rabbiteye blueberries.

The observation that the increased $\mathrm{C}$ demand by new shoots of $\mathrm{NO}_{3}{ }^{-}$-fertilized plants did not reduce $\mathrm{C}$ partitioning to other plant parts suggests that the current $C$ supply was sufficient for uptake of both $\mathrm{N}$ forms. Although the effects of $\mathrm{C}$ availability on uptake of different $\mathrm{N}$ forms in woody perennials has received little attention, there are a few studies on the effects of $\mathrm{C}$ availability on $\mathrm{NO}_{3}^{-}$uptake. In mature prune trees (Weinbaum et al., 1978) and peach (Prunus persica L. cv. Maycrest) trees (Munoz et al., 1993), $\mathrm{NO}_{3}{ }^{-}$uptake rates were actually higher during rapid shoot development, suggesting that $\mathrm{C}$ availability was not limiting in these

Table 4. ${ }^{15}$ Nitrogen-enriched fertilizer nitrogen content and concentration in vegetative organs, and the percentage of total fertilizer $\mathrm{N}$ recovered in the shoots of 'Sharpblue' blueberries fertilized with $\mathrm{NH}_{4}{ }^{+}$or $\mathrm{NO}_{3}{ }^{-}$. Plants were fertilized with ${ }^{15} \mathrm{~N}$-enriched $\mathrm{NH}_{4}^{+}$or $\mathrm{NO}_{3}{ }^{-}$and harvested $12 \mathrm{~h}$ after labeling.

\begin{tabular}{|c|c|c|c|c|c|c|}
\hline & Plant & New shoots & Leaves & Stems & Roots & Shoot N/total N (\%) \\
\hline \multicolumn{7}{|c|}{ Nitrogen content $(\mathrm{mg})$} \\
\hline $\mathrm{NH}_{4}^{+}$ & 44.9 & 3.3 & 0.5 & 4.0 & 36.9 & 17.4 \\
\hline \multirow{2}{*}{$\mathrm{NO}_{3}^{-}$} & 42.5 & 5.1 & 0.6 & 5.0 & 31.9 & 26.5 \\
\hline & NS & NS & NS & NS & NS & NS \\
\hline \multicolumn{7}{|c|}{ Nitrogen concn $\left(\mu g \cdot g^{-1} d r y w t\right)$} \\
\hline \multirow{3}{*}{$\begin{array}{l}\mathrm{NH}_{4}^{+} \\
\mathrm{NO}_{3}^{-}\end{array}$} & 125.0 & 67.0 & 20.0 & 39.0 & 203.0 & \\
\hline & 78.0 & 107.0 & 17.0 & 30.0 & 108.0 & \\
\hline & * & NS & NS & NS & $*$ & \\
\hline
\end{tabular}

\footnotetext{
NS, ${ }^{*}$ Nonsignificant or significant at $P=0.05$ by $t$ test.
} 
Table 5. Relative specific activity (RSA) of vegetative organs of 'Sharpblue' blueberry plants fertilized with $\mathrm{NH}_{4}^{+}$or $\mathrm{NO}_{3}{ }^{-}$. Plants were harvested $12 \mathrm{~h}$ after labeling with ${ }^{14} \mathrm{CO}_{2}$.

\begin{tabular}{lcccc}
\hline & \multicolumn{4}{c}{ RSA $(\%$ dpm/\% dry wt $)$} \\
\cline { 2 - 5 } & New shoots & Leaves & Stems & Roots \\
\hline $\mathrm{NH}_{4}{ }^{+}$ & 4.96 & 3.19 & 0.29 & 0.10 \\
$\mathrm{NO}_{3}{ }^{-}$ & 6.68 & 4.39 & 0.29 & 0.08 \\
& $*$ & NS & NS & NS \\
\hline
\end{tabular}

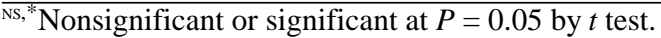

crops. In contrast, the greatest $\mathrm{NO}_{3}^{-}$uptake in 'Helleri' holly occurred between flushes of growth, rather than during the growth of the vegetative flush (Gilliam and Wright, 1978). However, plants in that study were small, rooted cuttings, and may have lacked sufficient carbohydrate sources to support both vegetative growth and $\mathrm{N}$ uptake. In the present study, the 2-year-old blueberry plants apparently had sufficient carbohydrates available to support both vegetative growth and $\mathrm{N}$ uptake.

Based on these observations, it appears that although southern highbush blueberry plants are able to take up $\mathrm{NH}_{4}{ }^{+}-\mathrm{N}$ and $\mathrm{NO}_{3}{ }^{-} \mathrm{N}$ when $\mathrm{pH}$ is maintained in a range considered optimum for blueberry growth, the uptake of $\mathrm{NO}_{3}^{-}-\mathrm{N}$ is limited relative to $\mathrm{NH}_{4}^{+}-\mathrm{N}$ uptake. However, this limitation to $\mathrm{NO}_{3}{ }^{-}$uptake clearly does not inhibit vegetative growth, provided that $\mathrm{pH}$ is maintained below 6.0. Thus, the hypothesis that growth inhibition of $\mathrm{NO}_{3}^{-}$-fertilized blueberries is due directly to inadequate uptake of $\mathrm{NO}_{3}^{-}$does not appear to be valid under the conditions of this study. It also appears that, under conditions of this study, adequate current and/or total carbohydrates are available to support both vegetative growth and $\mathrm{N}\left(\right.$ as $\mathrm{NO}_{3}^{-}$or $\mathrm{NH}_{4}^{+}$) assimilation in blueberry.

\section{Literature Cited}

Austin, M.E. and T.P. Gaines. 1984. An observation of nutrient levels in old, unfertilized rabbiteye blueberry plants. HortScience 19:417-418.

Ballinger, W.E. 1962. Studies of sulfate and chloride ion effects upon Wolcott blueberry growth and composition. Proc. Amer. Soc. Hort. Sci. 80:331-339.

Brady, N.C. 1990. The nature and properties of soils. 10th ed. Macmillan Publishing Co., New York.

Brun, W.A. and K.J. Betts. 1984. Source/sink relations of abscising and nonabscising soybean flowers. Plant Physiol. 75:187-191.

Cain, J.C. 1952. A comparison of ammonium and nitrate nitrogen for blueberries. Proc. Amer. Soc. Hort. Sci. 59:161-166.

Clark, J.R. 1988. Comparison of elemental content of leaves form highbush and rabbiteye blueberries. Ark. Farm Res. May-June:12.

Eck, P. 1988. Blueberry science. Rutgers Univ. Press, London.

Glass, A.D.M. 1989. Plant nutrition: An introduction to current concepts. Jones and Bartlett Publishers, Boston.

Gilliam, C.H. and R.D. Wright. 1978. Timing of fertilizer application in relation to growth flushes of 'Helleri' holly (Ilex crenata Thunb.). HortScience 13:300-301.

Greidanus, T., L.A. Peterson, L.E. Schrader, and M.N. Dana. 1972. Essentiality of ammonium for cranberry nutrition. J. Amer. Soc. Hort. Sci. 97:272-277.

Haby, V.A., K.D. Patten, D.L. Cawthon, B.B. Krejsa, E.W. Neuendorff, J.V. Davis, and S.C. Peters. 1986. Response of container-grown rabbiteye blueberry plants to irrigation water quality and soil type. J. Amer. Soc. Hort. Sci. 322-337.

Hammett, L.K. and W.E. Ballinger. 1972. A nutrient solution-sand culture system for studying the influence of $\mathrm{N}$ form on highbush blueberries. HortScience 7:498-499.

Hewitt, E.J. 1966. Sand and water culture methods used in the study of plant nutrition. Commonwealth Agr. Bureaux, England.

Korcak, R.F. 1986. Adaptability of blueberry species to various soil types: II. Leaf and soil analysis. J. Amer. Soc. Hort. Sci. 111:822-828.
Korcak, R.F. 1988. Nutrition of blueberry and other calcifuges. Hort. Rev. 10:183-227.

Lewis, O.A.M., B. Fulton, and A.A.A. Zelewski. 1987. Differential distribution of carbon in response to nitrate, ammonium, and nitrate + ammonium nutrition in wheat, p. 240-246. In: W.R. Ullrich, P.J. Aparico, P.J. Syurett, and F. Castillo (eds.). Inorganic nitrogen metabolism. Springer Verlag, New York.

McClure, P.R., L.V. Kochian, R.M. Spanswick, and J.E. Shaff. 1990a. Evidence for cotransport of nitrate and protons with ion-selective microelectrodes. Plant Physiol. 93:290-294.

McClure, P.R., L.V. Kochian, R.M. Spanswick, and J.E. Shaff. 1990b. Evidence for cotransport of nitrate and protons in maize roots. II. Measurement of $\mathrm{NO}_{3}^{-}$and $\mathrm{H}^{+}$fluxes with ion-selective microelectrodes. Plant Physiol. 93:290-2904.

Merhaut, D.J. 1993. Effects of nitrogen form on vegetative growth, and carbon/nitrogen assimilation, metabolism, and partitioning in blueberry. $\mathrm{PhD}$ diss., Univ. of Florida, Gainesville. (Diss. Abstr. 95-05801.)

Merhaut, D.J. and R.L. Darnell. 1995. Ammonium and nitrate accumulation in containerized southern highbush blueberry plants. HortScience 30:13781381.

Munoz, N., J. Guerri, F. Legaz, and E. Primo-Millo. 1993. Seasonal uptake of ${ }^{15} \mathrm{~N}$-nitrate and distribution of absorbed nitrogen in peach trees. Plant Soil. 150:263-269.

Oertli, J.J. 1963. Effect of form of nitrogen and $\mathrm{pH}$ on growth of blueberry plants. Agron. J. 55:305-307.

Peterson, L.A., E.J. Stang, and M.N. Dana. 1988. Blueberry response to $\mathrm{NH}_{4}^{+}-\mathrm{N}$ and $\mathrm{NO}_{3}^{-}$-N. J. Amer. Soc. Hort. Sci. 113:9-12.

Rideout, J.W. and C.D. Raper, Jr. 1994. Diurnal changes in net uptake rate of nitrate are associated with changes in estimated export of carbohydrates to roots. Intl. J. Plant Sci. 155:173-179.

Rosen, C.J., D.L. Allan, and J.J. Luby. 1990. Nitrogen form and solution pH influence growth and nutrition of two Vaccinium clones. J. Amer. Soc. Hort. Sci. 115:83-89.

Smith, R.L., H.A. Mills, C.S. Hoveland, and W.W. Hanna. 1990. Influence of ammonium:nitrate ratios on the growth and nitrogen uptake of pearl millet. J. Plant Nutr. 13:541-553.

Spiers, J.M. 1978. Effects of pH level and nitrogen source on elemental leaf content of 'Tifblue' rabbiteye blueberry. J. Amer. Soc. Hort. Sci. 103:705708.

Spiers, J.M. 1983a. Elemental leaf content and deficiency symptoms in rabbiteye blueberries: 1. Nitrogen. J. Plant Nutr. 6:1059-1071.

Spiers, J.M. 1983b. Influence of N, K, and Na concentration on growth and leaf element content of 'Tifblue' rabbiteye blueberry. HortScience 18:223224.

Sugiyama, N. and S. Hanawa. 1992. Growth responses of rabbiteye blueberry plants to $\mathrm{N}$ forms at constant $\mathrm{pH}$ in solution culture. J. Jpn. Soc. Hort. Sci. 61:25-29.

Sugiyama, N. and M. Hirooka. 1993. Uptake of ammonium-nitrogen by blueberry plants. J. Plant Nutr. 16:1975-1981.

Sugiyama, N. and K. Ishigaki. 1994. Uptake of nitrate-nitrogen by blueberry plants. J. Plant Nutr. 17:1975-1982.

Takamizo, T. and N. Sugiyama. 1991. Growth responses to N forms in rabbiteye and highbush blueberries. J. Jpn. Soc. Hort. Sci. 60:41-45.

Tolley-Henry, L. and C.D. Raper, Jr. 1989. Cyclic variations in nitrogen uptake rate of soybean plants: Ammonium as a nitrogen source. Plant. Physiol. 91:1345-1350.

Townsend, L.R. 1967. Effect of ammonium nitrogen and nitrate nitrogen, separately and in combination, on the growth of highbush blueberry. Can. J. Plant Sci. 47:555-562.

Townsend, L.R. 1969. Influence of form of nitrogen and $\mathrm{pH}$ on growth and nutrient levels in the leaves and roots of the lowbush blueberry. Can. J. Plant Sci. 49:333-338.

Townsend, L.R. 1970. Effect of form of $\mathrm{N}$ and $\mathrm{pH}$ on nitrate reductase activity in lowbush blueberry leaves and roots. Can. J. Plant. Sci. 50:603605.

Wang, S.Y. and R.F. Korcak. 1995. Effect of nutrient and cytokinins on nitrate reductase activity in blueberry. J. Small Fruit and Viticult. (In press.) Weinbaum, S.A., M.L. Merwin, and T.T. Muraoka. 1978. Seasonal variation in nitrate uptake efficiency distribution of absorbed nitrogen in nonbearing trees. J. Amer. Soc. Hort. Sci. 103:516-519. 